\title{
CLOSED TRAUMATIC RUPTURE OF THE CERVICAL TRACHEA
}

\author{
BY \\ E. F. SOOTHILL \\ From Norfolk and Norwich Hospital
}

(RECEIVED FOR PUBLICATION NOVEMBER 20, 1959)

Rupture of the trachea is a rare accident. Injuries that are a part of open wounds in the cervical region are usually due to suicidal cutthroat or to gunshot wounds. Their emergency treatment and early repair or late reconstruction present a distinct surgical problem (Scott, 1928 ; Knight, 1946 ; Longmire, 1948 ; Maisel and Dingwall, 1950). Rupture of the thoracic trachea may occur in severe closed crushing chest injuries and be associated with rupture of the bronchi and damage to the chest wall.

Closed rupture of the cervical air duct is occasionally spontaneous, but is usually the result of direct or indirect violence. This may either tear the fibro-elastic component circumferentially, separating a tracheal ring from the cricoid or its neighbour, or cause single or multiple fractures of the cartilages of the larynx or trachea.

Zeuch (1922) collected from the literature a series of cases of closed rupture of the trachea including separation from the larynx, fracture of the cartilages, and intrathoracic rupture, adding a case of his own to the previous 53. Forty-four of the cases were probably cervical as far as the description allows the distinction. Four were spontaneous, due apparently to sudden extension of the neck in fright, straining in labour against a closed glottis, the cough of croup in an infant, and violent, expulsive coughing in the presence of a foreign body impacted in the larynx. Most were due to blows on the front of the neck, even a trivial knock causing rupture in some. The posture and intratracheal pressure were considered to be factors determining the type and extent of the damage inflicted. His own patient, a boy of 7 , fell, striking his neck on the pedal of a toy tricycle. At first pain was slight and the neck appeared normal. Rapidly increasing surgical emphysema, first seen in the neck, and stridor and cyanosis indicated the diagnosis. Release of air by multiple punctures improved the condition. The neck was immediately explored under ether anaesthesia and a transverse rent between the second and third tracheal rings was found. This was repaired and the neck closed, without tracheostomy or drainage, the patient recovering uneventfully. His conclusion was that rupture of the trachea should be treated by early exploration and repair. Conservative measures were followed by high morbidity and mortality, due most commonly to suffocation from mediastinal surgical emphysema and subsequent infection.

The Table summarizes the mode of injury, the diagnostic symptoms and signs, the investigations carried out, the details of injuries found, the treatment provided, and the end-results achieved for the cases published since 1922. These authors concur on most points. The violence may be slight, the airway may be little impaired despite a severe injury, and surgical emphysema may be absent or extreme and appear at any interval after the injury. Fractures of the larynx and cricotracheal separation are particularly liable to lead to stenosis with or without the effects of bilateral recurrent laryngeal nerve injury.

\section{CASE History}

The patient whose injuries are now described was admitted to the Norfolk and Norwich Hospital on August 22, 1958.

Mr. R.M., a fit man of 43 , was standing between a loading bay and the rear of a trailer, when a mechanical horse was backed into it in order to take it in tow. The trailer moved backward too quickly for him to escape and struck his upper chest and right shoulder and rode up on to his neck extending it over the loading bay for a brief period. He was quickly released and brought to hospital.

$\mathrm{He}$ complained of pain in the front of his neck especially on swallowing, and of haemoptysis. He had no particular difficulty in breathing and could talk hoarsely. While in the Casualty Department he was anxious and in some pain, but he was only slightly cyanosed with quiet respiration at 24 per minute. Small haemoptysis was repeated and increasing surgical emphysema confined to the front of the neck was noticed. 
TABLE

REPORTED SERIES OF RUPTURED CERVICAL TRACHEA

\begin{tabular}{|c|c|c|c|c|c|c|c|c|}
\hline Author & Age & Sex & $\begin{array}{l}\text { Type of } \\
\text { Trauma }\end{array}$ & $\begin{array}{l}\text { Signs and } \\
\text { Symptoms }\end{array}$ & Investigations & Injury & Treatment & Result \\
\hline Zeuch (1922) & 7 & $\mathbf{M}$ & $\begin{array}{l}\text { Fell off cycle and } \\
\text { struck neck }\end{array}$ & $\begin{array}{l}\text { Immediate sur- } \\
\text { gical emphys- } \\
\text { ema of neck }\end{array}$ & None & $\begin{array}{l}\text { Ruptured trachea } \\
\text { 2nd and 3rd } \\
\text { rings }\end{array}$ & $\begin{array}{l}\text { Immediate re- } \\
\text { lease of air by } \\
\text { punctures and } \\
\text { early repair. No } \\
\text { tracheostomy }\end{array}$ & $\begin{array}{l}\text { Uneventful re- } \\
\text { covery in two } \\
\text { weeks }\end{array}$ \\
\hline Taylor (1934) & $30-40$ & $\mathbf{M}$ & Motor accident & Found dead & , , & $\begin{array}{l}\text { Cricotracheal } \\
\text { separation. } \\
\text { Drowned in } \\
\text { blood }\end{array}$ & None & Dead \\
\hline $\begin{array}{l}\text { Desjacques } \\
\text { et al. (1939) }\end{array}$ & 70 & $\mathbf{M}$ & $\begin{array}{l}\text { Kicked in neck } \\
\text { by horse }\end{array}$ & $\begin{array}{l}\text { Extreme dys- } \\
\text { pnoea and } \\
\text { cyanosis }\end{array}$ & , & $\begin{array}{l}\text { Multiple frac- } \\
\text { tures of tracheal } \\
\text { cartilages }\end{array}$ & $\begin{array}{l}\text { Immediate } \\
\text { tracheostomy }\end{array}$ & $\begin{array}{l}\text { Uneventful re- } \\
\text { covery in three } \\
\text { weeks }\end{array}$ \\
\hline Foster (1939) & Adult & $\mathbf{M}$ & $\begin{array}{l}\text { Glancing blow } \\
\text { on chest, pos- } \\
\text { sibly while } \\
\text { straining }\end{array}$ & $\begin{array}{l}\text { Immediate surgi- } \\
\text { cal emphysema } \\
\text { of neck and se- } \\
\text { vere dyspnoea }\end{array}$ & , , & $\begin{array}{l}\text { Ruptured trachea } \\
\text { just below the } \\
\text { cricoid }\end{array}$ & $\begin{array}{l}\text { Emergency high } \\
\text { tracheostomy } \\
\text { injuring cricoid, } \\
\text { late repair }\end{array}$ & $\begin{array}{l}\text { Recovery in two } \\
\text { months, hoarse } \\
\text { voice }\end{array}$ \\
\hline $\begin{array}{l}\text { Cummings } \\
(1940)\end{array}$ & 26 & $\mathbf{M}$ & $\begin{array}{l}\text { Motor collision } \\
\text { - struck neck } \\
\text { on seat }\end{array}$ & $\begin{array}{l}\text { Dyspnoea, } \\
\text { aphonia, haem- } \\
\text { optysis and } \\
\text { surgical emphy- } \\
\text { sema of neck }\end{array}$ & $\begin{array}{l}\text { Indirect } \\
\text { laryngoscopy } \\
\text { inconclusive }\end{array}$ & $\begin{array}{l}\text { Ruptured trachea } \\
\text { 1 } 1 \text { in. below } \\
\text { cords }\end{array}$ & $\begin{array}{l}\text { Tracheostomy } \\
\text { on to broncho- } \\
\text { scope at } 24 \mathrm{hr} \text {. } \\
\text { Late division } \\
\text { and dilatation } \\
\text { of stricture }\end{array}$ & $\begin{array}{l}\text { Recovery in six } \\
\text { months, hoarse } \\
\text { voice }\end{array}$ \\
\hline $\begin{array}{l}\text { Nach and } \\
\text { Rothman } \\
(1943)\end{array}$ & 25 & $\mathbf{M}$ & Kicked in neck & $\begin{array}{l}\text { Surgical emphys- } \\
\text { ema of neck }\end{array}$ & None & Not explored & Conservative & $\begin{array}{l}\text { Uneventful re- } \\
\text { covery in one } \\
\text { week }\end{array}$ \\
\hline , & 55 & $\mathbf{F}$ & Motor accident & $\begin{array}{l}\text { Surgical emphys- } \\
\text { ema of neck and } \\
\text { late dyspnoea }\end{array}$ & , & , & $\begin{array}{l}\text { Emergency } \\
\text { tracheostomy } \\
\text { on 4th day }\end{array}$ & $\begin{array}{l}\text { Recovery after } \\
\text { infection in two- } \\
\text { three weeks }\end{array}$ \\
\hline , & 31 & $\mathbf{F}$ & Kicked in neck & $\begin{array}{l}\text { Surgical emphys- } \\
\text { ema of neck }\end{array}$ & , , & , & $\begin{array}{l}\text { Release of air by } \\
\text { punctures }\end{array}$ & $\begin{array}{l}\text { Recovery after } \\
\text { infection in } \\
\text { three weeks }\end{array}$ \\
\hline $\begin{array}{l}\text { Jackson and } \\
\text { Jackson } \\
\text { (1948) }\end{array}$ & 16 & $\mathbf{M}$ & $\begin{array}{l}\text { Struck on neck } \\
\text { while " coast- } \\
\text { ing" }\end{array}$ & $\begin{array}{l}\text { Late dyspnoea } \\
\text { and haemo- } \\
\text { ptysis }\end{array}$ & $\begin{array}{l}\text { Radiograph } \\
\text { negative. } \\
\text { Bronchoscopy } \\
\text {-haemorrhagic } \\
\text { swelling bulging } \\
\text { into trachea }\end{array}$ & $\begin{array}{l}\text { Contusion of } \\
\text { trachea }\end{array}$ & $\begin{array}{l}\text { Emergency } \\
\text { bronchoscopy } \\
\text { relieved and } \\
\text { tracheostomy } \\
\text { on to it }\end{array}$ & $\begin{array}{l}\text { Uneventful full } \\
\text { recovery in five } \\
\text { weeks }\end{array}$ \\
\hline Dysart (1949) & 15 & $\mathbf{M}$ & $\begin{array}{l}\text { Rode motorcycle } \\
\text { into chain and } \\
\text { struck neck }\end{array}$ & $\begin{array}{l}\text { Haemoptysis, } \\
\text { painful swallow- } \\
\text { ing and hoarse } \\
\text { voice. No sur- } \\
\text { gical emphys- } \\
\text { ema }\end{array}$ & $\begin{array}{l}\text { Indirect laryng- } \\
\text { oscopy-fixed } \\
\text { cords. Bronch- } \\
\text { oscopy (LA)- } \\
\text { rupture seen }\end{array}$ & $\begin{array}{l}\text { Cricotracheal } \\
\text { separation. Bi- } \\
\text { lateral recurrent } \\
\text { laryngeal nerve } \\
\text { injury }\end{array}$ & $\begin{array}{l}\text { Exploration } \\
\text { (L A), repair } \\
\text { indwelling } \\
\text { laryngeal tube, } \\
\text { tracheostomy } \\
\text { and repeated }\end{array}$ & $\begin{array}{l}\text { Recovery after } \\
\text { nine months. } \\
\text { Hoarse voice } \\
\text { and stenosis }\end{array}$ \\
\hline Metson (1953) & 6 & $\mathbf{M}$ & $\begin{array}{l}\text { Pushed against } \\
\text { fence and st ruck } \\
\text { neck }\end{array}$ & $\begin{array}{l}\text { Pain and late } \\
\text { surgical } \\
\text { emphysema } \\
\text { after coughing }\end{array}$ & $\begin{array}{l}\text { Chest radiograph } \\
\text {-mediastinal } \\
\text { emphysema. } \\
\text { Late bronchos- }\end{array}$ & Not explored & $\begin{array}{l}\text { dilatation } \\
\text { Conservative }\end{array}$ & $\begin{array}{l}\text { Full recovery in } \\
\text { two weeks }\end{array}$ \\
\hline , , , & 4 & $\mathbf{M}$ & $\begin{array}{l}\text { Fell from tricycle } \\
\text { and struck neck }\end{array}$ & $\begin{array}{l}\text { Immediate sur- } \\
\text { gical emphys- } \\
\text { ema of neck } \\
\text { and dyspnoea }\end{array}$ & $\begin{array}{l}\text { Chest radiograph } \\
\text {-mediastinal } \\
\text { emphysema. } \\
\text { Early bronch- }\end{array}$ & , , & $\begin{array}{l}\text { Early tracheos- } \\
\text { tomy }\end{array}$ & $\begin{array}{l}\text { Uneventful full } \\
\text { recovery }\end{array}$ \\
\hline Fox (1955) & $?$ & Boy & $\begin{array}{l}\text { Motor accident } \\
\text {-injuries to } \\
\text { face and neck }\end{array}$ & $\begin{array}{l}\text { Dyspnoea and } \\
\text { surgical } \\
\text { emphysema of } \\
\text { neck }\end{array}$ & $\begin{array}{l}\text { oscopy } \\
\text { None }\end{array}$ & $\begin{array}{l}\text { Rupturedtrachea } \\
\text { 2nd ring with } \\
\text { wide separation } \\
\text { and vertical } \\
\text { tear. Bilateral } \\
\text { recurrent laryn- } \\
\text { geal nerveinjury }\end{array}$ & $\begin{array}{l}\text { Immediate } \\
\text { tracheostomy } \\
\text { and repair } \\
(\mathrm{L} A)\end{array}$ & $\begin{array}{c}\text { Recovery in } \\
\text { three weeks, } \\
\text { hoarse voice }\end{array}$ \\
\hline Beskin (1957) & 40 & $\mathbf{M}$ & $\begin{array}{l}\text { Motor accident } \\
\text { - multiple } \\
\text { injuries }\end{array}$ & $\begin{array}{l}\text { Cyanosis, dys- } \\
\text { pnoea, surgical } \\
\text { emphysema and } \\
\text { no better after } \\
\text { chest injuries } \\
\text { treated }\end{array}$ & $\begin{array}{l}\text { Chest radiograph } \\
\text { - fractured ribs } \\
\text { and pneumo- } \\
\text { thorax }\end{array}$ & $\begin{array}{l}\text { Ruptured trachea } \\
\text { "just below } \\
\text { larynx" with } \\
\text { wide separation }\end{array}$ & $\begin{array}{l}\text { Early exploration } \\
\text { and repair } \\
\text { (L A). Trach- } \\
\text { eostomy below }\end{array}$ & $\begin{array}{l}\text { Full recovery } \\
\text { after infection } \\
\text { in three weeks }\end{array}$ \\
\hline
\end{tabular}

On admission his general condition and colour were good. The pulse was $80 / \mathrm{min}$., respiration $20 / \mathrm{min}$., and the blood pressure was $125 / 68 \mathrm{~mm}$. $\mathrm{Hg}$. Bruising and scraping in an upward direction in a line over the upper sternum, right clavicle, and shoulder, and a small abrasion over the spine of the right scapula were present. There was a large but well-localized swelling, due largely to air in the tissues, overlying the trachea. This region was bruised and tender. There was no evidence of bony injury to sternum, ribs, or shoulder, and chest movement was full and pain-free. Coarse rales were heard throughout both lungs. Other systems were normal.

A radiograph of the chest showed the surgical emphysema of the neck but no pneumothorax or $\frac{\varrho}{\sigma}$ evidence of chest wall or pulmonary injury. There was no evidence of mediastinal emphysema. 
In view of the severe and localized tenderness and leak of air in the region of the trachea and oesophagus, it was decided that bronchoscopy and oesophagoscopy should be performed to assess the injury. This was performed under general anaesthesia the same evening, with the instruments necessary for an immediate tracheostomy set out ready should an obstruction to the passage of an instrument or tube into the trachea be encountered. In fact the induction of anaesthesia was smooth and the bronchoscope was passed easily into the trachea. It was first passed well down, and the blood and mucus were aspirated from both bronchi and lower trachea, which were normal. A damaged area on the anterior wall of the trachea about an inch below the cords was then inspected. It extended around the anterior and lateral walls, and irregular tearing and bruising of the mucosa were all that could be made out. An endotracheal tube was then passed and oesophagoscopy performed, revealing no abnormality.

It was decided that the proper course was to explore the neck with the purpose of performing at least a tracheostomy.

OPERATION.-Through a transverse skin incision the strap muscles were separated in the midline. This opened an air-containing space into which the end of the endotracheal tube was projecting through a transverse tear between the third and fourth rings of the trachea. While the fibromuscular wall posteriorly was still in continuity, the mucosa was completely torn circumferentially. The endotracheal tube was immediately placed in the distal trachea. The trachea was then repaired by means of interrupted 0 chromic catgut sutures. leaving a defect anteriorly into which a tracheostomy tube fitted closely. The wound was closed with drainage.

Post-operative recovery was uneventful. The tracheostomy tube was removed on the ninth day and the fistula healed rapidly. The patient was discharged to his home on the fourteenth day after the operation. Six weeks later he was admitted for bronchoscopy, which revealed a $2 \mathrm{~mm}$. ridge encircling the trachea one inch below the cords, ending anteriorly in a pit, the site of the healed tracheostomy. This constriction was slight and would not be sufficient to affect normal function. At that time and since he has remained physically well.

\section{Discussion}

Rupture of the cervical air passages by closed trauma is diagnosed on the history and the progression of the physical signs. It may occur in association with other injuries, those of the chest being particularly liable to mask it. Surgical emphysema appearing in and spreading from the anterior aspect of the neck at any interval after a local injury, pain on swallowing, hoarseness of the voice, and haemoptysis are the characteristic features. Obstruction of the airway may be present in varying degree and require urgent treatment, but is frequently absent even in complete transverse rupture. The surrounding structures apparently form a sufficiently rigid tube for the patients to breathe through unless severe haemorrhage occurs from them. Fractures of the larynx are particularly likely to result in suffocation. It may be difficult, as in the case described, to decide whether rupture is due to a direct blow or to violent extension of the neck or to both factors operating in sequence. The possibility of associated injury to the cervical spine must be kept in mind.

Minor tears of the trachea can occur and remain undiagnosed, while others may produce widespread surgical emphysema, the extent of which bears no relationship to the degree of local injury. It may at times be difficult to decide from what point the leak of air has taken place. A normal chest radiograph suggests that surgical emphysema arising in the neck comes from the cervical trachea if the oesophagus can be excluded. Minor degrees of pneumothorax may be missed or air may leak from torn lung adherent by previous disease, but it may be possible to exclude these mechanisms by which air may reach the tissues of the neck. Mediastinal surgical emphysema may arise from any part of the trachea, bronchi, or oesophagus and can rupture into one or both pleural cavities even at an early stage. This sequence of events might obscure the site of primary injury, the mediastinal emphysema becoming radiologically less well marked and the uni- or bilateral pneumothoraces focusing attention on the chest regarding both diagnosis and treatment. Metson (1953) discusses the effects of progressive surgical emphysema of the mediastinal and lung roots and quotes experimental work. Tamponade of the great vessels, unilateral or bilateral pneumothorax, and pneumopericardium are said to occur, though little clinical evidence is available (Goldstein, 1949).

Acute respiratory distress precludes investigation and demands immediate tracheostomy with or without local analgesia according to the degree of urgency. Where a reasonable airway remains investigation is helpful.

Indirect laryngoscopy is desirable in these cases when possible, in order to assess cord movement and the function of the recurrent laryngeal nerves before operative interference is begun for prognostic and legal purposes.

In the absence of obstruction requiring immediate tracheostomy, the decision has to be made whether bronchoscopy should be performed. General anaesthesia is preferable in view of the difficulty in suppressing pain from the injured 
structures in the neck with local analgesia. This is not dangerous so long as the surgeon is ready, before induction is started, to expose the trachea at a moment's notice and provided that the stomach is empty and closed drainage of any pneumothorax is established. Bronchoscopy under these conditions allows accurate assessment of any injury that may be present and the thorough aspiration of the air passages, and should be performed when any suspicion of rupture of the trachea is aroused.

In addition it is probably wise to perform an oesophagoscopy at the same time. The history recorded here indicates a hazard inherent in such cases. The endotracheal tube passing out of the trachea into the neck as a result of pressure from behind by the oesophagoscope might also have completed the obstruction it was intended to prevent, and demanded immediate incision.

The neck should be explored when, in any patient in whom the injury is suspected, bronchoscopy reveals a significant abnormality or when surgical emphysema becomes sufficiently tense and extensive to be likely to spread into the mediastinum. The aims of such action are to perform a tracheostomy, to arrest haemorrhage, to release surgical emphysema, and to repair the rupture. A transverse incision through skin and platysma with midline separation of the infrahyoid muscles and retraction or division of the thyroid isthmus provides adequate exposure. It would be unwise to search for the recurrent laryngeal nerves even though one or both were known to be functionless, since the risk of further damage being inflicted would be great and the prospect of improvement being achieved by it remote.

The exact method of repair is probably of little importance. Some favour stainless steel wire, and others chromic catgut, which proved very satisfactory in this presented case. It has been shown that stainless steel wire is the material of choice for suturing the bronchi from the absence of inflammatory reaction to it and the associated reduction of stenosis to a minimum. The trachea has little tendency to stenosis after primary healing and its lumen in adults allows some stricture formation with impunity. Injuries affecting the larynx are more likely to result in strictures and should be repaired with stainless steel wire. Interrupted sutures, some of them taking a hold in the cartilaginous rings, are desirable.

The formation of a tracheostomy at or below the suture line is not really necessary in most cases according to the published accounts. However, it is a temporary infliction that is little burden कै to the patient and should be established without hesitation should age, pre-existing chest disease, associated chest injury, or injury close to or involving the larynx render obstruction of the airway or retention of sputum likely complications. If not performed at the time of operation facilities to do it at any time without delay thereafter must be always available. From the evidence of the quoted case the use of the suture line as a site for the tracheostomy if at a convenient level is satisfactory and does not apparently stimulate stricture formation. Tracheostomy is certainly preferable to any form of indwelling laryngeal tube.

The wound should be closed with catgut for the fasciomuscular layers and should be drained whether tracheostomy has or has not been performed. The after-care is as for any thoracic operation, deep breathing being encouraged and expectoration being assisted by suction through the tracheostomy should one have been established. The removal of the tracheostomy tube should be permissible when the fistula track has been firmly established, the wound is healthy, the chest has been cleared of infection, and there is evidence that neither cord paralysis nor traumatic stricture has resulted in an inadequate airway through the larynx.

I should like to thank Mr. E. C. Wynne Edwards for his permission to publish this case and for his help in preparing this paper.

\section{REFERENCES}

Beskin, C. A. (1957). J. thorac. Surg., 34, 392.

Cummings, G. O. (1940). Ann. Otol. (St. Louis), 49, 801. Cummings, G. O. (1940). Ann. Otol. (St. Louis), 49, 801.
Desjacques, Bondet, and Mounier-Kuhn (1939). Lyon méd., 163 (1),

Dysart, B. R. (1949). Laryngoscope (St . Louis), 59, 502.

Foster, J. H. (1939). Ann. Otol. (St. Louis), 48, 643.

Fox, R. (1955). J. thorac. Surg., 29, 253.

Goldstein, P. (1949). Amer.J. Dis. Child., 78, 375

Jackson, C., and Jackson, C. L. (1948). In Lewis' Practice of Surgery, N Vol. IV, Ch. 7, p. 52 . Hagerstown, Prior, Maryland, U.S.A. Knight, J. S. (1946). Ann. Otol. (St. Louis), 55, 656.

Longmire, W. P., Jr. (1948). Ibid., 57, 875.

Maisel, B., and Dingwall, J. A. (1950). Surgery, 27, 726.

Metson, B. F. (1953). A.M.A. Arch. Otolaryng., 57, 182.

Nach, R. L., and Rothman, M. (1943). Surg. Gynec. Obstet., 76, 614 Scott, G. D. (1928). J. Amer. med. Ass., $90,689$.

Taylor, J. (1934). J. Laryng., 49,593 .

Zeuch, L. H. (1922). Illinois med. J., 41, 451. 